\title{
Generation Mean Analysis for Metric Traits in Urdbean (Vigna mungo [L.] Hepper)
}

\author{
A. V.S. Durga Prasad ${ }^{1 *}$ and E. Murugan ${ }^{2}$ \\ ${ }^{I}$ Department of Genetics and Plant Breeding, RARS, Maruteru, India \\ ${ }^{2}$ Department of Genetics and Plant Breeding, AC\& RI, Madurai, India \\ *Corresponding author
}

\section{A B S T R A C T}

\section{Keywords}

Generation mean analysis, Scaling tests, Epistatic interactions and Urdbean

\section{Article Info}

Accepted:

20 December 2020

Available Online:

10 January 2021
The nature and magnitude of gene action was analyzed using six generation mean for seed yield and its attributes in three inter-varietal crosses of urdbean. A perusal of generation mean analysis (GMA) indicated that a simple additive-dominance model was inadequate and an epistatic model had to be assumed as seen from the significance of scaling tests. Further the GMA revealed that seed yield and its component traits were influenced by different types of gene action viz., additive, dominance and epistatic interactions, cheifly of dominance $\mathrm{x}$ dominance and duplicate dominant types. Hence, improvement of these traits is impossible with simple selection techniques, as they are unable to fix in superior lines. Therefore, deferment in selection of superior lines to later generations is practised in pedigree method of breeding to make it effective. However to harness epistatic interactions, one or two cycles of recurrent selection followed by pedigree breeding method would be effective and useful to identify superior lines with high yield and yield components.

\section{Introduction}

Urdbean $(2 \mathrm{n}=2 \mathrm{x}=22)$, a premier short duration food legume with photo-thermo insensitive nature and soil fertility ameliorator capacity, serves as an ideal option for crop intensification and diversification. Besides, it is an excellent source of high quality easily digestible dietary protein $(25-28 \%)$, oil (1.0$1.5 \%)$, fiber $(3.5 \%-4.5 \%)$, ash $(4.5-5.5 \%)$, carbohydrates $(62-65 \%)$, low flatulence and fair supplier of lysine, vitamins, iron and phosphorus. To evolve high yielding promising genotypes in urdbean, studies on nature and magnitude of gene effects of metric traits is imperative to unravel their complex inheritance for designing and formulation of efficient breeding strategies.

In self-pollinated crops like urdbean, an approach based on generation mean analysis has particular suitability as in addition to additive and dominance gene effect, as it also estimates the type of epistasis present. Hence in the current study, an attempt has been made to estimate gene effects operative for control of seed yield and its attributes by using six generation means in three inter varietal crosses of urdbean. 


\section{Materials and Methods}

The experimental material in present investigation comprises of three inter-varietal crosses of urdbean viz., Co $5 \times$ PU $31\left(\mathrm{C}_{1}\right)$, Co $5 \mathrm{x} \operatorname{VBN}(\mathrm{Bg}) 4\left(\mathrm{C}_{2}\right)$ and Co $5 \mathrm{x} \operatorname{VBN}(\mathrm{Bg}) 6$ $\left(\mathrm{C}_{3}\right)$. Six generations viz., $\mathrm{P}_{1}, \mathrm{P}_{2}, \mathrm{~F}_{1}, \mathrm{~F}_{2}, \mathrm{~B}_{1}$ and $B_{2}$ of these three crosses $\left(C_{1}, C_{2}\right.$ and $\left.C_{3}\right)$ were sown in compact family block design with two replications, raised on ridges of two metre length spaced at $30 \mathrm{~cm}$ between ridges and $10 \mathrm{~cm}$ between plants for evaluation during kharif, 2014 at National Pulses Research Centre, Vamban. Recommended agronomic packages of practices were followed to raise the healthy crop. The number of plants studied in each of the six generations in each of the three inter-varietal crosses are given below.

\begin{tabular}{|c|c|c|c|c|}
\hline S. No. & Generation & $\begin{array}{c}\text { No. of rows / } \\
\text { replication }\end{array}$ & $\begin{array}{c}\text { No. of plants studied in } \\
\text { each replication }\end{array}$ & $\begin{array}{c}\text { Total No. of } \\
\text { plants studied }\end{array}$ \\
\hline $\mathbf{1}$ & $\mathrm{P}_{1}$ & 1 & 20 & 40 \\
\hline $\mathbf{2}$ & $\mathrm{P}_{2}$ & 1 & 20 & 40 \\
\hline $\mathbf{3}$ & $\mathrm{F}_{1}$ & 1 & 20 & 40 \\
\hline $\mathbf{4}$ & $\mathrm{F}_{2}$ & 8 & 160 & 320 \\
\hline $\mathbf{5}$ & $\mathrm{B}_{1}$ & 3 & 60 & 120 \\
\hline $\mathbf{6}$ & $\mathrm{B}_{2}$ & 3 & 60 & 120 \\
\hline
\end{tabular}

Data were recorded on selected plants in each replication for nine quantitative traits viz., days to $50 \%$ flowering, plant height, number of branches / plant, number of clusters / plant, number of pods / plant, number of seeds / pod, hundred seed weight and seed yield / plant. Simple scaling test A, B, and C of Mather (1949) was used to detect presence of the epistasis. Six parameter model advocated by Hayman (1958) was used to obtain estimate of $\mathrm{m}, \mathrm{d}, \mathrm{h}, \mathrm{i}, \mathrm{j}$ and $\mathrm{l}$ parameters.

\section{Results and Discussion}

The estimates of mean for six generations viz., $\mathrm{P}_{1}, \mathrm{P}_{2}, \mathrm{~F}_{1}, \mathrm{~F}_{2}, \mathrm{~B}_{1}$ and $\mathrm{B}_{2}$; scaling test $(\mathrm{A}, \mathrm{B}$ and $\mathrm{C}$ scales) and the gene effects viz., additive, dominance and epistatic interaction for the three inter-varietal crosses of urdbean are presented for seed yield and its attributes in Tables 1 and 2.

\section{Days to $50 \%$ flowering}

In parents, the $\mathrm{P}_{1}$ mean was higher than $\mathrm{P}_{2}$ in all the three crosses studied. The $F_{1}$ mean was found to be intermediate when compared to their parents in all the crosses. The $F_{2}$ mean was higher than $F_{1}$ mean in all the three crosses. The $B_{1}$ mean exceeded the $F_{1}$ mean in crosses $\mathrm{C}_{1}$ and $\mathrm{C}_{2}$ and lesser in cross $\mathrm{C}_{3}$. In $\mathrm{B}_{2}$, the mean was less than $\mathrm{F}_{1}$ in all the crosses and it was more pronounced in cross $\mathrm{C}_{2}$.

The scaling test revealed that the (i) scale $\mathrm{B}$ was significant in the crosses $\mathrm{C}_{2}$ and $\mathrm{C}_{3}$ (ii) scale $C$ was significant in crosses $C_{1}$ and $C_{3}$. Hence, a simple additive-dominance model was inadequate for all the crosses studied. The natural origin $\mathrm{m}$ was positive and significant in all the crosses and also the $\mathrm{m}$ effect was greater than all other effects. The additive effect (d) was positive and significant in all the crosses, except in cross $\mathrm{C}_{3}$ where it was non-significant. A positively significant dominance effect (h) was noticed in cross $\mathrm{C}_{1}$. The additive $\mathrm{x}$ additive interaction (i) was negatively significant in crosses $\mathrm{C}_{1}$ and $\mathrm{C}_{3}$ and positively significant in cross $C_{1}$. The additive $x$ dominance interaction ( $j$ ) was negatively significant in cross $\mathrm{C}_{3}$ only whereas it was 
positive in crosses $\mathrm{C}_{2}$ and $\mathrm{C}_{1}$ with significance and non-significance respectively. Positive and significant dominance $\mathrm{x}$ dominance (l) interaction effect was registered in the cross $\mathrm{C}_{2}$ only while it was positive non-significant in cross $\mathrm{C}_{3}$ and negatively significant in cross $C_{1}$.

Thus additive, dominance and all the three types of epistatic interactions govern this trait. Jahagiridar (2001) and Rahecha et al., (2006) reported additive gene action for this trait. Kute and Deshmukh (2002), Vasline et al., (2007), Anbu Selvam and Elangaimannan (2010), Supriyo Chakraborty et al., (2010), Isha Parveen et al., (2012), Selvam (2012), Gill et al., (2014) and Vijay Kumar et al., (2014) reported the predominance of dominance effect for this trait. Murugan (2005) and Ram et al., (2013) noticed that both additive and dominance variance contribute for this trait. All the three types of epistatic interactions were reported by Kute and Deshmukh (2002), Murugan (2005), Singh et al., (2007) and Ramakant and Srivastava (2012) to govern this trait.

\section{Plant height}

In all the crosses, the $\mathrm{P}_{1}$ mean was greater than $\mathrm{P}_{2}$ mean. The $\mathrm{F}_{1}$ was found to be intermediate in all the crosses. In all the three crosses, the $\mathrm{F}_{2}$ mean was greater than that of respective $F_{1}$ mean. The $B_{1}$ mean exceeded the $F_{1}$ mean in all the crosses. Compared to $\mathrm{F}_{1}$ mean, the $\mathrm{B}_{2}$ mean was found to be more in crosses $\mathrm{C}_{2}$ and $\mathrm{C}_{3}$ while it was less in cross $\mathrm{C}_{1}$.

An epistatic model had to be assumed for all the crosses as indicated by the scaling test. The scale A was found to be positive and nonsignificant in all the crosses. The scale $\mathrm{B}$ showed significance positive in cross $C_{3}$. The scale $\mathrm{C}$ showed positive significance in all the crosses.
The ' $\mathrm{m}$ ' was positive and significant in all the crosses and also the ' $\mathrm{m}$ ' effect was also greater than all other effects. The additive effect (d) was positive and significant in all the crosses. The dominance effect (h) was negatively significant in the crosses $\mathrm{C}_{1}$ and $\mathrm{C}_{2}$ while it was positively non-significant in the cross $C_{3}$. The additive $x$ additive (i) effect was negative with significance in crosses $C_{1}$ and $\mathrm{C}_{3}$ and non-significant in cross $\mathrm{C}_{2}$. The additive $\mathrm{x}$ dominance effect $(\mathrm{j})$ was negative with significance in $\operatorname{cross}_{3}$ and nonsignificant in cross $\mathrm{C}_{1}$ while positive nonsignificant in cross $\mathrm{C}_{2}$. The dominance $\mathrm{x}$ dominance (l) interaction effect was nonsignificant in crosses $\mathrm{C}_{1}$ and $\mathrm{C}_{2}$ whereas it was negative with significance, non-significant in cross $\mathrm{C}_{3}$ only.

Thus additive, dominance and all the three types of epistasis had governed this trait. Several workers like Jiji Joseph and Santhosh Kumar et al., (2000 a), Manivannan (2002), Vaithiyalingam et al., (2002), Singh and Dikshit (2003), Anbumalarmathi et al., (2004), Murugan (2005), Vasline et al., (2007), Anbu Selvam and Elangaimannan (2010), Supriyo Chakraborty et al., (2010), Selvam (2012), Gill et al., (2014) and Vijay Kumar et al., (2014) had observed greater dominance variance for this trait. However, additive gene action was also reported by few workers like Rahecha et al., (2006) and Isha Parveen et al., (2012). All the three types of epistasis was registered by Khattak et al., (2002), Murugan (2005), Singh et al., (2007) and Ramakant and Srivastava (2012).

\section{Number of branches / plant}

In all the crosses, the $\mathrm{P}_{1}$ mean was higher than $\mathrm{P}_{2}$ mean in all the crosses. The $\mathrm{F}_{1}$ mean was greater than the parental means in all the crosses. The $F_{2}$ mean was found to be drastically lesser than the $F_{1}$ mean in all the crosses. The $\mathrm{B}_{1}$ mean was on par or lesser 
than the respective recurrent parent in all the crosses. In $\mathrm{B}_{2}$, the mean was higher than the respective recurrent parent for all the crosses.

The scale A was negative and non-significant in all the crosses. The scale $\mathrm{B}$ was nonsignificant in cross $C_{2}$ whereas positively non-significant in the crosses $\mathrm{C}_{1}$ and $\mathrm{C}_{3}$. The scale $\mathrm{C}$ was negatively significant in all the crosses. Hence, a simple additive-dominance model was inadequate for all the three crosses.
The $m$ effect was positively significant and greater than other effects in all the crosses. The additive effect (d) was positively nonsignificant in all the crosses. The dominance effect (h) was positively non-significant in all the crosses. The additive $\mathrm{x}$ additive (i) effect was positively significant in cross $\mathrm{C}_{3}$ only and non-significant in the remaining crosses. The additive $x$ dominance effect (j) and dominance $\mathrm{x}$ dominance (1) interaction effect were negatively non-significant for all the crosses.

Table.1 Estimates of scaling test for seed yield and its attributes in urdbean

\begin{tabular}{|c|c|c|c|c|}
\hline \multirow[t]{2}{*}{ Character } & \multirow[t]{2}{*}{ Scaling test } & \multicolumn{3}{|c|}{ Cross } \\
\hline & & $\mathbf{C}_{1}$ & $\mathrm{C}_{2}$ & $\mathbf{C}_{3}$ \\
\hline \multirow[t]{3}{*}{ Days to $50 \%$ flowering } & A & $1.23+0.45$ & $-0.47 \pm 0.44$ & $-0.43 \pm 0.38$ \\
\hline & B & $1.03+0.41$ & $-2.47 * * \pm 0.45$ & $1.10 * * \pm 0.43$ \\
\hline & $\mathrm{C}$ & $-7.40 * \pm 0.65$ & $1.12 \pm 0.70$ & $-2.24 * * \pm 0.74$ \\
\hline \multirow[t]{3}{*}{ Plant height } & A & $0.37 \pm 2.28$ & $2.33 \pm 1.98$ & $1.87 \pm 1.92$ \\
\hline & $\mathrm{B}$ & $1.13 \pm 1.70$ & $0.97 \pm 1.49$ & $19.00 * * \pm 1.30$ \\
\hline & $\mathrm{C}$ & $12.50 * * \pm 3.81$ & $13.10 * *+3.01$ & $31.68 * * \pm 3.00$ \\
\hline \multirow[t]{3}{*}{ Number of branches/plant } & A & $-0.30 \pm 0.34$ & $-0.30 \pm 0.31$ & $-0.33 \pm 0.28$ \\
\hline & B & $0.17 \pm 0.30$ & $-0.07 \pm 0.30$ & $0.07 \pm 0.28$ \\
\hline & $\mathrm{C}$ & $-0.56^{*} \pm 0.45$ & $-0.82 * \pm 0.45$ & $-1.16^{* * \pm} \pm 0.44$ \\
\hline \multirow[t]{3}{*}{ Number of clusters/plant } & A & $-1.00 \pm 0.90$ & $-1.50 \pm 0.81$ & $-1.97 \pm 0.77$ \\
\hline & $\mathrm{B}$ & $-2.70 * * \pm 0.90$ & $-2.27 * * \pm 0.86$ & $-2.27 * * \pm 0.80$ \\
\hline & $\mathrm{C}$ & $-6.42 * * \pm 1.43$ & $-5.78 * * \pm 1.33$ & $-6.46 * * \pm 1.28$ \\
\hline \multirow[t]{3}{*}{ Number of pods/plant } & A & $-1.37 \pm 1.09$ & $-1.77 \pm 1.06$ & $-1.60 \pm 0.99$ \\
\hline & $\mathrm{B}$ & $0.37 \pm 1.04$ & $-0.03 \pm 1.03$ & $0.97 \pm 0.87$ \\
\hline & $\mathrm{C}$ & $-11.60 * * \pm 1.79$ & $-11.32 * * \pm 3.09$ & $-10.82 * * \pm 1.66$ \\
\hline \multirow[t]{3}{*}{ Pod length } & A & $-0.23 * * \pm 0.09$ & $-0.14 \pm 0.08$ & $-0.27 * * \pm 0.10$ \\
\hline & $\mathrm{B}$ & $0.05 \pm 0.08$ & $0.07 \pm 0.07$ & $-0.16 \pm 0.09$ \\
\hline & $\mathrm{C}$ & $-0.35^{*} \pm 0.14$ & $-0.22 * \pm 0.11$ & $-0.57 * * \pm 0.15$ \\
\hline \multirow[t]{3}{*}{ Number of seeds/pod } & A & $-0.63^{*} \pm 0.31$ & $-0.73 * * \pm 0.26$ & $-0.20 \pm 0.27$ \\
\hline & B & $-0.60 * \pm 0.30$ & $-0.50 \quad \pm 0.27$ & $-0.23 \pm 0.25$ \\
\hline & $\mathrm{C}$ & $-0.98 * \pm 0.49$ & $-0.90^{*} \pm 0.39$ & $-0.50 \pm 0.40$ \\
\hline \multirow[t]{3}{*}{ Hundred seed weight } & A & $-0.20 * * \pm 0.06$ & $-0.16^{* *} \pm 0.06$ & $-0.17 * * \pm 0.06$ \\
\hline & B & $-0.65 * * \pm 0.07$ & $-0.57 * * \pm 0.07$ & $-0.54 * * \pm 0.07$ \\
\hline & $\mathrm{C}$ & $-0.64 * * \pm 0.11$ & $-0.53 * * \pm 0.11$ & $-0.51 * * \pm 0.11$ \\
\hline \multirow[t]{3}{*}{ Seed yield/plant } & A & $-1.27 * * \pm 0.33$ & $-1.40 * * \pm 0.40$ & $-0.96^{*} \pm 0.41$ \\
\hline & $\mathrm{B}$ & $-1.88 * * \pm 0.37$ & $-1.75 * * \pm 0.29$ & $-1.13 * * \pm 0.38$ \\
\hline & $\mathrm{C}$ & $-4.82 * * \pm 0.59$ & $-4.55 * * \pm 0.49$ & $-4.57 * * \pm 0.61$ \\
\hline
\end{tabular}


Table.2 Estimates of gene action for seed yield and its attributes in urdbean

\begin{tabular}{|c|c|c|c|c|c|c|c|}
\hline \multirow[t]{2}{*}{ Character } & \multirow[t]{2}{*}{ Cross } & \multicolumn{6}{|c|}{ Gene action } \\
\hline & & m & d & H & $\mathbf{i}$ & $\mathbf{J}$ & l \\
\hline \multirow[t]{3}{*}{ Days to $50 \%$ flowering } & $\mathrm{C}_{1}$ & $23.13 * * \pm 0.54$ & $3.00 * * \pm 0.16$ & $21.70 * * \pm 1.44$ & $9.67 * * \pm 0.52$ & $0.10 \pm 0.26$ & $-11.93 * * \pm 1.03$ \\
\hline & $\mathbf{C}_{2}$ & $39.75 * * \pm 0.66$ & $0.30 * \pm 0.15$ & $-12.14 * * \pm 1.70$ & $-4.05 * * \pm 0.64$ & $1.00 * * \pm 0.27$ & $6.99 * * \pm 1.15$ \\
\hline & $\mathbf{C}_{3}$ & $37.07 * * \pm 0.68$ & $0.100 \pm 0.14$ & $-2.68 \pm 1.65$ & $-1.57 * \pm 0.66$ & $-0.77 * * \pm 0.24$ & $0.91 \pm 1.08$ \\
\hline \multirow[t]{3}{*}{ Plant height } & $\mathrm{C}_{1}$ & $57.15 * * \pm 3.19$ & $9.95 * * \pm 0.94$ & $-28.65^{* *} \pm 7.57$ & $-11.00 * * \pm 3.05$ & $-0.38 \pm 1.22$ & $9.50 \pm 4.94$ \\
\hline & $\mathbf{C}_{2}$ & $56.15^{* *} \pm 3.25$ & $7.25 * * \pm 0.65$ & $-25.65^{* *} \pm 7.99$ & $-9.80 \pm 3.18$ & $0.68 \pm 1.18$ & $6.50 \pm 4.97$ \\
\hline & $\mathbf{C}_{3}$ & $46.91 * * \pm 2.94$ & $17.40 * * \pm 0.66$ & $0.44 \pm 7.11$ & $-10.81 * * \pm 2.87$ & $-8.57 * * \pm 1.06$ & $-10.05^{*} \pm 4.47$ \\
\hline \multirow[t]{3}{*}{ Number of branches/plant } & $\mathbf{C}_{1}$ & $2.27 * * \pm 0.39$ & $0.20 \pm 0.14$ & $1.22 \pm 1.07$ & $0.43 \pm 0.37$ & $-0.23 \pm 0.21$ & $-0.29 \pm 0.74$ \\
\hline & $\mathbf{C}_{2}$ & $2.40 * * \pm 0.35$ & $0.15 \pm 0.13$ & $0.99 \pm 0.96$ & $0.45 \pm 0.33$ & \pm 0.19 & $-0.09 \pm 0.69$ \\
\hline & $\mathbf{C}_{3}$ & $2.01 * * \pm 0.34$ & $0.20 \pm 0.12$ & $1.92 * \pm 0.90$ & $0.90 * * \pm 0.32$ & \pm 0.17 & $-0.63 \pm 0.65$ \\
\hline \multirow[t]{3}{*}{ Number of clusters/plant } & $\mathrm{C}_{1}$ & $16.13 * * \pm 1.10$ & $-0.85 * * \pm 0.33$ & $1.69 \pm 2.92$ & $2.72 * * \pm 1.05$ & \pm 0.51 & $0.98 \pm 2.14$ \\
\hline & $\mathbf{C}_{2}$ & $16.84 * * \pm 1.06$ & $-0.55 \quad \pm 0.32$ & $0.41 \pm 2.77$ & $2.01^{*} \pm 1.01$ & \pm 0.49 & $1.75 \pm 1.98$ \\
\hline & $\mathbf{C}_{3}$ & $16.42 * * \pm 1.01$ & $-0.25 \pm 0.30$ & $1.27 \pm 2.62$ & $2.23^{*} \pm 0.96$ & \pm 0.46 & $2.01 \pm 1.87$ \\
\hline \multirow[t]{3}{*}{ Number of pods/plant } & $\mathrm{C}_{1}$ & $19.40 * * \pm 1.50$ & $-3.50 * * \pm 0.46$ & $26.20 * * \pm 3.76$ & $10.60 * * \pm 1.42$ & \pm 0.65 & $-9.60 * * \pm 2.55$ \\
\hline & $\mathbf{C}_{2}$ & $20.88 * * \pm 1.48$ & $-3.40 * * \pm 0.38$ & $22.74 * * \pm 3.73$ & $9.52 * * \pm 1.43$ & \pm 0.61 & $-7.72 * * \pm 2.58$ \\
\hline & $\mathbf{C}_{3}$ & $19.96 * * \pm 1.46$ & $-2.75 * * \pm 0.38$ & $25.19 * * \pm 3.57$ & $10.19 * * \pm 1.41$ & $-1.28 * \pm 0.57$ & $-9.55 * * \pm 2.36$ \\
\hline \multirow[t]{3}{*}{ Pod length } & $\mathrm{C}_{1}$ & $4.70 * * \pm 0.11$ & $0.34 * * \pm 0.03$ & $0.10 \pm 0.28$ & $0.17 \pm 0.10$ & $-0.14 * * \pm 0.05$ & $0.01 \pm 0.21$ \\
\hline & $\mathbf{C}_{2}$ & $4.73 * * \pm 0.11$ & $0.29 * * \pm 0.03$ & $0.11 \pm 0.28$ & $0.15 \pm 0.10$ & $-0.11^{*} \pm 0.05$ & $-0.08 \pm 0.19$ \\
\hline & $\mathbf{C}_{3}$ & $4.77 * * \pm 0.11$ & $0.23 * * \pm 0.03$ & $-0.13 \pm 0.28$ & $0.14 \pm 0.10$ & $-0.05 \pm 0.05$ & $0.29 \pm 0.21$ \\
\hline \multirow[t]{3}{*}{ Number of seeds/pod } & $\mathbf{C}_{1}$ & $6.00 * * \pm 0.34$ & $-0.05 \pm 0.10$ & $-1.29 \pm 0.90$ & $-0.25 \pm 0.32$ & $-0.02 \pm 0.16$ & $1.49 * \pm 0.70$ \\
\hline & $\mathbf{C}_{2}$ & $6.08 * * \pm 0.33$ & $0.05 \pm 0.10$ & $-1.45 \pm 0.90$ & $-0.33 \pm 0.32$ & $-0.12 \pm 0.16$ & $1.57^{*} \pm 0.63$ \\
\hline & $\mathbf{C}_{3}$ & $5.48 * * \pm 0.32$ & $-0.15 \pm 0.11$ & $0.35 \pm 0.84$ & $0.07 \quad \pm 0.30$ & $0.02 \pm 0.16$ & $0.37 \pm 0.60$ \\
\hline \multirow[t]{3}{*}{ Hundred seed weight } & $\mathrm{C}_{1}$ & $4.59 * * \pm 0.09$ & $-0.17 * * \pm 0.03$ & $-0.88 * * \pm 0.23$ & $-0.21 * \pm 0.09$ & $0.23 * * \pm 0.04$ & $1.06^{* * \pm 0} \pm 0.15$ \\
\hline & $\mathbf{C}_{2}$ & $4.57 * * \pm 0.09$ & $-0.15 * * \pm 0.03$ & $-0.78 * * \pm 0.22$ & $-0.20^{*} \pm 0.08$ & $0.21 * * \pm 0.04$ & $0.94 * * \pm 0.15$ \\
\hline & $\mathbf{C}_{3}$ & $4.58 * * \pm 0.09$ & $-0.15 * * \pm 0.03$ & $-0.76^{* *} \pm 0.21$ & $-0.21^{*} \pm 0.08$ & $0.18 * * \pm 0.04$ & $0.91 * * \pm 0.15$ \\
\hline \multirow[t]{3}{*}{ Seed yield/plant } & $\mathbf{C}_{1}$ & $4.77 * * \pm 0.51$ & $-1.44 * * \pm 0.11$ & $2.77 * \pm 1.29$ & $1.67 * * \pm 0.50$ & $0.30 \pm 0.20$ & $1.49 \pm 0.90$ \\
\hline & $\mathbf{C}_{2}$ & $5.32 * * \pm 0.56$ & $-1.16^{* * \pm 0} 0.10$ & $1.95 \pm 1.47$ & $1.40 * \pm 0.55$ & \pm 0.23 & $1.74 \pm 0.96$ \\
\hline & $\mathbf{C}_{3}$ & $3.90 * * \pm 0.59$ & $-1.05 * * \pm 0.14$ & $5.78 * * \pm 1.52$ & $2.48 * * \pm 0.57$ & \pm 0.25 & $-0.40 \pm 1.02$ \\
\hline
\end{tabular}

*Significance at $5 \%$ level of probability

**Significance at $1 \%$ level of probability 
Thus the presence of additive and dominant gene actions followed by all the three types of interaction and duplicate dominant interaction appeared to govern this trait. The results were in consonance with the findings by earlier workers for this trait. Dominant gene action was reported by Jiji Joseph and Santhosh Kumar (2000), Manivannan (2002), Vaithiyalingam et al., (2002), Anbumalarmathi et al., (2004) and Murugan (2005). All the three types of epistasis were noted by Murugan (2005).

\section{Number of clusters / plant}

The $\mathrm{P}_{2}$ mean was higher than the $\mathrm{P}_{1}$ mean in all the crosses. Compared to the parental means, the $\mathrm{F}_{1}$ mean was greater in cross $\mathrm{C}_{3}$ while it was intermediate in the remaining crosses. The $\mathrm{F}_{2}$ mean was less than the $\mathrm{F}_{1}$ mean in all the crosses. The $\mathrm{B}_{1}$ mean were lesser than the respective recurrent parent in all the crosses. In case of $\mathrm{B}_{2}$ also the similar trend was observed.

In the scaling test, the scale $\mathrm{B}$ and scale $\mathrm{C}$ were significant in all the crosses. Hence, a simple additive model was inadequate for all the crosses. The natural origin $\mathrm{m}$ was positively significant and greater than other effects in all the crosses. The additive effect (d) was negative with significant in crosses $C_{1}$ and non-significant in crosses $\mathrm{C}_{2}$ and $\mathrm{C}_{3}$. The dominance effect (h) was non-significant positively in all the crosses. The additive $\mathrm{x}$ additive (i) effect was positive and significant in all the crosses. The additive $\mathrm{x}$ dominance effect (j) was positive and non-significant in all the crosses. Positive non-significance of dominance $\mathrm{x}$ dominance (l) interaction effect was noticed in all the crosses.

Thus as a whole, the dominance effect was predominant followed by additive effect. In the epistaic interactions, the dominance $x$ dominance (l) and additive $\mathrm{x}$ additive (i) were important for this trait. Jiji Joseph and Santhosh Kumar (2000), Singh and Dikshit (2003) and Murugan (2005) reported dominance gene effect governing this trait. Both additive and dominance was attributed by Jahagiridar (2001) and Murugan (2005). The epistatic interaction was reported by various workers viz., Murugan (2005). Especially, Kute and Desmukh (2002) reported additive $\mathrm{x}$ additive interaction effect for this trait.

\section{Number of pods / plant}

In all the crosses, the $\mathrm{P}_{2}$ mean was higher than $\mathrm{P}_{1}$ mean. Compared to the parental means, it was observed the mean of $F_{1}$ was drastically higher in all the crosses. The $F_{2}$ mean was comparatively much lesser than the $F_{1}$ mean in all the crosses. Higher mean value was registered in $\mathrm{B}_{1}$ when compared to the respective recurrent parent in all the crosses. Compared to $\mathrm{P}_{2}$ mean, the $\mathrm{B}_{2}$ mean was found to be more in all the crosses.

In the scaling test, scale $\mathrm{C}$ was significant in all the crosses. The scale $\mathrm{B}$ was nonsignificant in all the crosses. Hence, a simple additive-dominance model was inadequate in all the three crosses. The natural origin $\mathrm{m}$ was positively significant in all the crosses and was found lesser than dominance effect (h) in all the crosses. The additive effect (d) was negatively significant in all the crosses. The dominance effect $(\mathrm{h})$ and additive $\mathrm{x}$ additive (i) effect were positively significant in all the crosses. The additive $x$ dominance effect (j) was negatively non-significant in crosses $C_{1}$ and $\mathrm{C}_{2}$, significant in cross $\mathrm{C}_{3}$ alone. Negative significance of dominance $\mathrm{x}$ dominance (l) interaction effect was noticed in all the crosses.

Thus, over all dominance followed additive and epistatic interactions mainly of dominance $\mathrm{x}$ dominance and additive $\mathrm{x}$ 
additive type with duplicate dominant type of gene action appear to govern this trait. Jiji Joseph and Santhosh Kumar (2000), Manivannan (2002), Singh and Dikshit (2003), Anbumalarmathi et al., (2004) and Murugan (2005) attributed the presence of dominant type of gene action governing this trait. Ganesamurthy and Seshadri (2002) and Murugan (2005) revealed the presence of epistatic interaction for this trait.

\section{Pod length}

In parents the mean pod length of $\mathrm{P}_{1}$ was higher than $\mathrm{P}_{2}$ in all the crosses. It was observed that the $F_{1}$ mean was intermediate in all the crosses compared to the parental means. In general, the $F_{2}$ mean was lesser than the $F_{1}$ mean in all the crosses except in cross $\mathrm{C}_{2}$ where it was on par. In $\mathrm{B}_{1}$, the mean was found to be lower than $\mathrm{P}_{1}$ in all the crosses. Contrary trend was observed in $\mathrm{B}_{2}$ where its mean was found to be higher than the respective recurrent parent.

In the scaling test, the scale $\mathrm{C}$ was negatively significant in all the crosses while the same trend was observed in the crosses $C_{1}$ and $C_{3}$ for scale $\mathrm{A}$. The scale $\mathrm{B}$ was non-significant and negative in the cross $C_{3}$ but positive in crosses $\mathrm{C}_{1}$ and $\mathrm{C}_{2}$.

The residual effect $m$ was positively significant and greater than other effects in all the crosses. The additive effect (d) was positively significant in all the crosses. However the dominance effect (h) was positive but non-significant in all the crosses. The additive $\mathrm{x}$ additive (i) effect was nonsignificant in all the crosses. The additive $x$ dominance effect (j) was negatively significant in crosses $\mathrm{C}_{1}$ and $\mathrm{C}_{2}$. The dominance $\mathrm{x}$ dominance (l) interaction effect exhibited non-significant positive sign in the crosses $C_{1}$ and $C_{3}$ while negative sign in the remaining cross, $\mathrm{C}_{2}$.
Thus additive, dominance and epistatic interactions mainly of additive $\mathrm{x}$ additive type governed this trait. Both additive and dominance effect was reported by Vaithiyalingam et al., (2002) for this trait. Murugan (2005) revealed the presence of all the three types of epistatic interaction for this trait.

\section{Number of seeds / pod}

The mean of $\mathrm{P}_{2}$ was higher than $\mathrm{P}_{1}$ in all the crosses except in the cross $\mathrm{C}_{2}$. The $\mathrm{F}_{1}$ mean was higher than both the parents in all the crosses. The $\mathrm{F}_{2}$ mean was drastically lower than the corresponding $F_{1}$ in all the crosses. The $\mathrm{B}_{1}$ mean was lower than the respective recurrent parent in all the crosses except in cross $\mathrm{C}_{3}$. Comparing the $\mathrm{P}_{2}$ mean, the $\mathrm{B}_{2}$ mean was superior in cross $\mathrm{C}_{3}$ only whereas it was on par in cross $C_{2}$ and inferior in the rest of the crosses.

In the scaling test, the scale $\mathrm{A}$ was negative and significant in the crosses $\mathrm{C}_{1}$ and $\mathrm{C}_{3}$. Similar trend was noticed for scale $\mathrm{B}$ where the cross $C_{1}$ exhibited negative significance with the rest being non-significant. The scale $\mathrm{C}$ showed negative significance for all the crosses except in cross $\mathrm{C}_{3}$ where nonsignificance was observed.

The natural origin $\mathrm{m}$ was found to be positively significant and greater than other effects in all the crosses. The additive effect (d) was negatively significant in the cross $C_{1}$ while it was non-significant in the remaining crosses. The dominance effect (h) was nonsignificant and negative in all the crosses except in cross $C_{2}$ where it was positive. The additive $\mathrm{x}$ additive effect (i) was nonsignificant and negative sign in the crosses $\mathrm{C}_{1}$ and $\mathrm{C}_{2}$. The additive $\mathrm{x}$ dominance effect $(\mathrm{j})$ and dominance $\mathrm{x}$ dominance (l) interaction effect exhibited non-significance and negative in the crosses $C_{1}$ and $C_{2}$. 
Thus additive, dominance and epistatic interactions mainly of dominance $x$ dominance and duplicate dominant interaction governed this trait. The predominance of additive effect was reported by Aher et al., (2001). Singh and Dikshit (2003), Anbumalarmathi et al., (2004) and Murgan (2005) reported the presence of non-additive gene action governing this trait. The dominance $\mathrm{x}$ dominance effect was earlier reported by Murugan (2005) for this trait.

\section{Hundred Seed weight}

The mean of $\mathrm{P}_{2}$ was higher than $\mathrm{P}_{1}$ in all the crosses. In $F_{1}$, the mean was higher than the corresponding parental means. The $\mathrm{F}_{2}$ mean was less than the respective $F_{1}$ mean in all the crosses. When comparing $\mathrm{B}_{1}$ mean with their respective recurrent parent, all the crosses showed greater mean values while vice-versa was observed in $\mathrm{B}_{2}$, where its mean was lower than their corresponding recurrent parent.

The scaling test revealed that all the three scales were negatively significant in all the crosses. The natural origin $\mathrm{m}$ was positively significant and greater than other effects in all the crosses. The additive effect (d) was negatively significant in all the crosses. The dominance effect $(\mathrm{h})$ and additive $\mathrm{x}$ additive effect (i) exhibited significant negatively in all the crosses. The additive $\mathrm{x}$ dominance effect (j) was significantly positive in all the crosses. Positive significance for dominance $x$ dominance (1) interaction effect was observed in all the crosses. The signs of (h) and (l) effects were opposite in all the three crosses.

Thus overall, additive, dominance, epistatic interactions and duplicate dominant interaction appear to govern this trait. Several workers had earlier reported for the nature of gene action governing hundred seed weight. Additive gene action was observed by Indrani Dana and Das Gupta (2001) and Aher et al.,
(2001). The non-additive gene action was registered by Jehagiridar (2001), Vaithiyalingam et al., (2002), Singh and Dikshit (2003) and Anbumalarmathi et al., (2004). Contrary, duplicate dominant epistasis was registered by Murugan (2005).

\section{Seed yield / plant}

In all the crosses, the $\mathrm{P}_{2}$ mean was greater than the $\mathrm{P}_{1}$ mean. The $\mathrm{F}_{1}$ mean was greater than both the parents in all the crosses. In $\mathrm{F}_{2}$, there was a marked reduction in the mean values when compared to the respective $F_{1}$ mean for all the crosses. The mean of $B_{1}$ was far superior to their respective recurrent parent in all the crosses. The $\mathrm{B}_{2}$ mean was found inferior to their corresponding recurrent parent except in cross $\mathrm{C}_{3}$ where it was found superior.

In scaling test, all the three scales were found to be negatively significant in the crosses. The natural origin $m$ was found to be positively significant and greater than other effects in all the crosses. The additive effect (d) was negatively significant in all the crosses. The dominance effect (h) was positive and significant in all the crosses except in cross $\mathrm{C}_{2}$. The additive $\mathrm{x}$ additive effect (i) was positively significant in all the crosses. The additive $x$ dominance effect (j) was nonsignificant in all the crosses. Positive nonsignificance for dominance $\mathrm{x}$ dominance (l) interaction effect was observed in all the crosses.

As a whole, additive, dominance and epistatic interactions especially of dominance $x$ dominance and duplicate dominant interaction appear to govern this trait. The manifestation of additive gene action was reported by Aher et al., (2001). Earlier workers like Jiji Joseph and Santhosh Kumar (2000), Pooran Chand and Raghunadha Rao (2002), Manivannan (2002), Vaithiyalingam et al., (2002 a), 
Anbumalarmathi et al., (2004) and Murugan (2005) reported the preponderance of dominance effect. Both additive and dominance gene action was reported by Indrani Dana and Das Gupta (2001). The additive $\mathrm{x}$ additive interaction effect (i) was reported by Kute and Desmukh (2002) and Ganesamurthy and Seshadri for this trait. The preponderance of dominance $\mathrm{x}$ dominance interaction effect (1) was noted by Murugan (2005) for this trait. All the three types of epistatic interaction were reported by Murugan (2005) for this trait.

In conclusion the generation mean analysis revealed that all the nine yield and yield contributing traits were influenced by different types of gene action viz., additive, dominance and epistatic interactions cheifly of dominance $\mathrm{x}$ dominance and duplicate dominant types. Hence, improvement of these traits is impossible with simple selection techniques as they are unable to fix in superior lines. Therefore, deferment in selection of superior lines to later generations is practised in pedigree method of breeding to make it effective. However to harness epistatic interactions, one or two cycles of recurrent selection followed by pedigree breeding method would be effective and useful to identify superior lines with high yield and yield components.

\section{Acknowledgements}

The first author is highly thankful to ICAR for providing Senior Research Fellowship (2014-2015) for PhD study at Tamil Nadu Agricultural University, Coimbatore.

\section{References}

Aher, R.P., S.N. Mate and L.N. Tagad. (2006). Effect of Morpho-physiological parameters on yield and yield contributing characters in germplasm of blackgram (Vigna mungo (L.) Hepper).Legume Research, 29(2): 154-
156.

Anbumalarmathi, J., P. Rangasamy and S. Babu. (2004). Combining ability and heterosis for yield and yield components in greengram. (Vigna radiata (L.)Wilczek). Madras Agricultural Journal, 91(1-3): 79-82.

Anbuselvam, Y. and R. Elangaimannan. (2010). Combining ability analysis for yield and its component traits in blackgram (Vigna mungo (L.) Hepper). Electronic Journal of Plant Breeding, 1(6): 1386-1391.

Ganesamurthy, K. and P.Seshadri. (2002). Genetic architecture of seed yield and yield components in soybean (Glycine max (L.) Merill.). Madras Agricultural Journal, 89(4-6):302-303.

Gill, R.K., Inderjit Singh, Sarvjeet Singh and Pritpal Singh. (2014). Studies on combining ability for grain yield and component traits in kharif urdbean. Legume Research, 37(6): 575-579.

Hayman, B.I. (1958). The separation of epistatic from additive and dominance variation in generation means. Heredity, 12:371-390.

Indirani Dana and T. Dasgupta. (2001). Combining ability in blackgram. Indian Journal of Genetics,61(2):170-171.

Isha Parveen, S., M. Reddi Sekhar, D. Mohan Reddy and P. Sudhakar. (2012). Combining ability analysis for yield and yield components in urdbean (Vigna mungo (L.) Hepper).TheAndhra Agricultural Journal, 59(3): 390-397.

Jahagirdar, J.E. (2001). Heterosis and combining ability studies for seed yield and yield components in mungbean. Indian Journal of Pulses Research, 14(2): 141-142.

Jiji Joseph and A.V. Santhoshkumar. (2000). Genetic analysis of metric traits in greengram (Vigna radiata (L.)Wilczek.). International Journal of Tropical Agriculture, 18(2): 133-139.

Khattak, G.S.S., M.A. Haq, M. Ashraf, A.J. Khan and R. Zamir. (2002). Genetic architecture of secondary yield components in mungbean (Vigna radiata (L.) Wilczek.). Breeding Science, 52(4):235-241.

Kute, N.S. and R.B. Deshmukh. (2002). Genetic analysis in mungbean (Vigna radiata (L.) Wilczek.).Legume Research, 25(4):258261. 
Manivannan, N. (2002). Line x Tester analysis in kharif greengram. Legume Research, 25(2):127-130.

Mather, K. (1949). Biometrical Genetics.Dover publications, Inc., New York.

Murugan, E. (2005). Genetic studies for improvement of yield and yellow mosaic virus disease resistance in blackgram (Vigna mungo (L.) Hepper).Ph.D Thesis, Tamil Nadu Agricultural. University, Madurai.

Pooran Chand and C. Raghunadha Rao. (2002). Studies on gene action in a biparental cross in blackgram (Vigna mungo (L.) Hepper).Indian Journal of Genetics, 62(4):347-348.

Rahecha., N.S., R.F. Chaudhari, K.N. Chaudhari and F.P. Chaudhari. (2006). Selection of superior combiners in mung bean. Journal of Arid Legumes, 3(2): 34-36.

Ram, B., S.B.S. Tikka and S. Acharya. (2013). Heterosis and combining ability in blackgram (Vigna mungo) under different environments. Indian Journal of Agricultural Sciences, 83(6): 23-28.

Ramakant and A.K. Srivasatava. (2012). Inheritance of some quantitative characters in urdbean (Vigna mungo (L.) Hepper). Journal of Food Legumes, 25(1): 1-8.

Selvam, A.Y. (2012). Diallel analysis in greengram (Vigna radiata L. Wilczek). International Journal of Recent Scientific Research, 3(5): 297-299.

Singh, A.K., R.K. Gautam, P.K. Singh, K.Kumar, N. Kumar, S.Swain and S.D. Roy. (2014). Estimation of genetic variability and association analysis in the indigenous landraces of urdbean (Vigna mungo L. Hepper) of Andaman islands. Vegetos, 27 (1): $113-122$.

Singh, D.P. (1980). Inheritance of resistance to yellow mosaic virus in blackgram (Vigna mungo(L.)Hepper).Theoretical Applied Genetics, 57:233-235.

Singh, B.B and H.K. Dikshit. (2003). Combining ability studies for yield and architectural traits in mungbean (Vigna radiata (L.) Wilczek.). Indian Journal of Genetics, 63(4):351-352.

Singh, V.K., K. Tyagi, A.K. Tomer, M.N. Singh and R. Nandan. (2007). Gene action for yield and yield attributing traits in mungbean [Vigna radiata (L.) Wilczek]. Legume Research, 30(1): 29-32.

Supriyo Chakraborty, Hironya K. Borah, Birinchi K. Borah, Dalim Pathak, Bipin K. Baruah, Hemen Kalita and Bhubaneswar Barman. (2010). Genetic parameters and combining ability effects of parents for seed yield and other quantitative traits in blackgram (Vigna mungo (L.) Hepper). Notulae Scientia Biologicae, 2(2):121-126.

Vaithiyalingam, M., S. Chidambaram., P. Vivekanandan and C. Vanniarajan. (2002). Combining ability studies in blackgram (Vigna mungo (L.) Hepper). Crop Research, 24(1):81-85.

Vasline, Y.A., V. Suguna and S. Padmavathi. (2007). Combining ability for seed yield and its components in greengram (Vigna radiata (L.) Wilczak).Crop Improvement, 34(2): 163-165.

Vijay Kumar, G., M. Vanaja, P. Raghu Ram Reddy, K. Salini, Babu Abraham and N. Jyothi Lakshmi. (2014). Studies on combining ability and genetic advance in blackgram (Vigna mungo (L.) Hepper). Research \& Reviews: Journal of Agriculture and Allied Sciences, 3(3): 1424.

\section{How to cite this article:}

Durga Prasad, A. V. S. and Murugan, E. 2021. Generation Mean Analysis for Metric Traits in Urdbean (Vigna mungo [L.] Hepper). Int.J.Curr.Microbiol.App.Sci. 10(01): 3104-3113. doi: https://doi.org/10.20546/ijcmas.2021.1001.361 